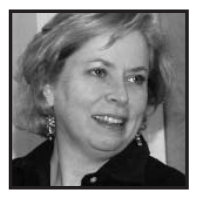

\title{
Saying What You See in the Dark: Engaging Children Through Art
}

\author{
Mary Ann Reilly, Morris School District
}

\section{ABSTRACT}

In this article, I explore the process of transmediation by examining selected art conversations-nonverbal communication made through painting - and poetry that urban fifth graders composed in response to a query about how they learn. Specifically, I examine three students' works, noting how the use of multiple symbol systems helped each to compose strong visual and written texts. In studying the work the students composed, I conclude that visual art and poetry make fine partners in intellectual endeavors aimed at educating the imagination.

$\mathrm{t}$ is late evening as I sit at my desk, reading students' poems - the sun long gone from the sky and the college where I work grown quiet. I have been so engrossed in reading students' work that when I read Ariana's (all names are pseudonyms) poem for the first time, I feel jolted, jazzed. Her poem stops me from moving forward to read the others, and I reread her poem that expresses how she learns and thinks. Ariana has titled the poem, "Swirls" (see Figure 1).

\section{Swirls of ideas}

Whirl like colors of light.

Ideas float like streams

And I row in the boat

Using an oar

To get to the shore. 
Learning is the key.

I flutter

Like a butterfly

In the breeze

Above the water.

My thoughts flow.

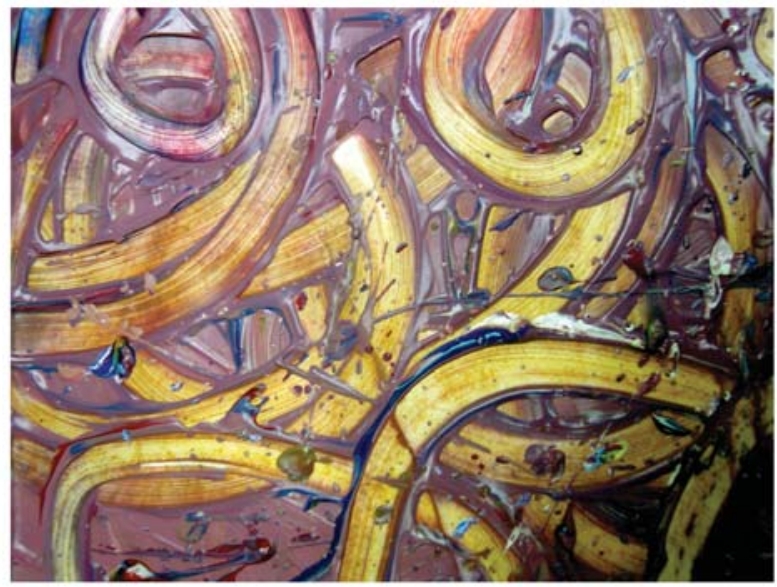

Fig. 1: Ariana's poem and a photograph of Ariana's art conversation

Ariana composed "Swirls" after she had engaged in an art conversation (Reilly, 2008; Reilly \& Cohen, 2008; Reilly \& Gangi, in press), a nonverbal discussion two or more people have using paint as a medium. During an art conversation, pairs "discuss" a particular topic or experience by remaining quiet while they finger paint. Seated opposite one another, with a sheet of glossy white paper (12"x 18") and some paint between them, "the partners engage in a 15- to 20-minute conversation letting the movement, selection of color, use of line, employment of form, and the inclusion of images and icons speak" (Reilly, 2008, p. 101). Ariana's art conversation occurred in response to a question I had posed to her and her classmates about how they had learned while engaged earlier in the year in a storytelling workshop and science inquiry lesson.

\section{Professional Development School: Benjamin Franklin Elementary School}

Benjamin Franklin Elementary School (pseudonym), an urban public school in New York serving 645 students who range from 5- to 12-years-old, partners as a Professional Development School (PDS) with a private college in New York. As a PDS, faculty from Benjamin Franklin School works closely with college faculty through a variety of methods. For example, many undergraduate and graduate methods courses are taught at Benjamin Franklin, placing pre-service teachers in elementary classrooms. In these situations the college professor and the classroom teacher collaborate by co-planning instruction, modeling teaching and providing pre-service teachers with scaffolded opportunities to teach. In addition to these field-based 
courses and more traditional student teaching practice, special projects also are developed between faculty at each institution, such as the work described in this article.

The genesis of the project described here began when the education Dean invited three faculty members from the college and the principal of the K-5 public school (Wepner, Bettica, Gangi, Reilly, \& Klemm, 2008) to work collaboratively. This partnership, funded by an external grant, addressed a need identified by the elementary school's PDS Leadership Team who "determined that the teachers needed to expand the curriculum beyond basic skills instruction while helping their students, especially Hispanic students, to demonstrate the necessary skills and strategies for succeeding with informal and formal assessments" (Wepner et al., p. 28). The education Dean forwarded a proposal that focused on engaging fifth graders through cross-curricular learning to the PDS committee, who approved the project. In this article I focus attention on one aspect of the project, namely the generation of art and poetry by fifth grade students.

During a four-month period in early 2007, all 100 fifth-grade students from Benjamin Franklin participated in three engagements designed by college faculty. Beginning in February, fifth graders learned how to choose and tell stories through a storytelling workshop taught by literacy professor Jane Gangi and her undergraduate education students. During this time the fifth graders selected stories to tell, often choosing ones that came from their culture, participated in two storytelling workshops, practiced telling their stories to one another, and then performed these stories for classmates as well as for students and teachers in other grades.

This experience was followed by a study of forensics in March of 2007. Modeled after the Parker Brothers' board game, CLUETM, the biology professor Annemarie Bettica and several undergraduate students guided fifth graders to solve a fictitious murder using science. During this engagement, students working in teams collected and analyzed fingerprint, blood, and fiber clues. They recorded and discussed their findings in order to determine the murderer. The use of forensics as a problem-solving tool was emphasized. I concluded this three-part experience in April and May of 2007 by engaging students in an art and poetry workshop that asked students to explore how they had learned to tell a story and the processes they used to determine the murderer. 


\section{Engaging in Art Conversations}

When students completed their work as storytellers, I asked them (through my request to their classroom teachers) to write about what and how they had learned during Professor Gangi's workshop. After reading students' responses, I synthesized their thinking and created four posters that re-presented their ideas as word collages (see Figure 2). These color posters contained quotations I had extracted from students' written work. I prepared these posters in order to better prompt students' memories. When groups of students-usually about 22-25 per group-arrived in the school's art room at the start of our 2-hour workshop, they found copies of each poster at their tables. I invited students to read and discuss each poster and then I charted their responses to the questions: How did you learn? How do you think?

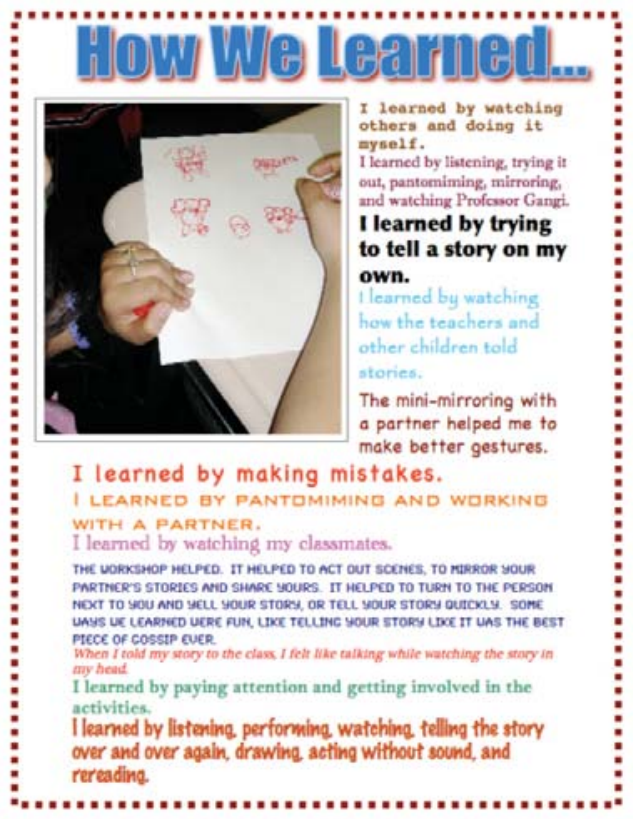

Fig. 2: How We Learned poster

Next, I showed the fifth graders a brief film I had made using photographs Professor Bettica had taken of the students while involved in the science lesson. I made the film using Animoto (http://www.animoto.com), a Web application that automatically produces a film by analyzing the selected photographs and music. The process is quick and the end product is professionally rendered. In less than a halfhour, a film can be produced. 
While students watched the film, I prompted their viewing by asking them to notice their learning. "Pay attention to the ways you think and learn, not just what you learned," I said, emphasizing the process. I interrupted their viewing several times to ask students to name how they saw themselves and their peers learning and added this information to the chart.

After viewing the film and discussing how they learned in each engagement, students "conversed" about how they learn and think through art conversations (see Figure 3 for a description of materials and processes). While students were engaged in these conversations I photographed them at work, and then photographed each completed art conversation. A genesis of one conversation is shown in Figure 4.

\section{MATERIALS}

Finger paint: Primary colors as well as black and white

Glossy finger paint paper (12" x 18")

Paint trays

Music

\section{PROCESS}

1. After an engagement, students use art conversations to "discuss" what they have either experienced or learned. I have used art conversations after students had viewed a film, engaged in drama, viewed art, read fiction and nonfiction.

2. At each station is a paint tray, usually filled with six different colors and a sheet of glossy fingerpaint paper.

3. Students are seated opposite one another.

4. Working as partners, students use the paint to show how they feel and think. During the painting time, students are silent. I usually play music while students paint.

5. I encourage students to use the whole sheet of paper, not only what they perceive as "their" side.

6. Although students may begin painting while seated, they almost always ended up standing as the work progresses.

7. Generally art conversations take place for about 15 to 20 minutes.

8. It is important to photograph the conversation while it is wet. When fingerpaint dries, it loses much of its color.

Fig. 3: Materials and processes for art conversations 

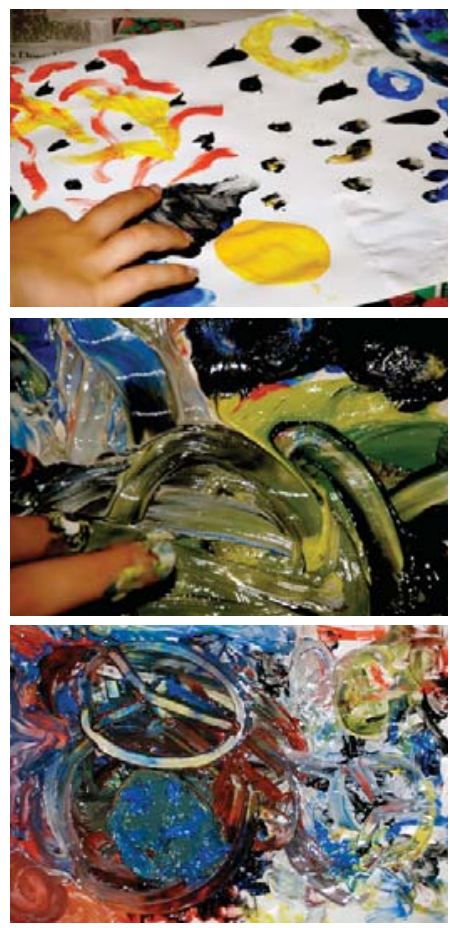

Fig.4: A genesis of an art conversation

As can be seen in Figure 4, art conversations often reflect multiple modes of representation: mimetic, expressive, and iconic. At first, many students rely on mimetic modes to communicate ideas to their partner. Mimetic forms look like their intended object; for example, a yellow circle is used to represent the sun. However, as students continue conversing, layers of paint are added, obscuring these mimetic images, leaving the painting looking more expressive. Here line, color, texture, value, and movement become dominant and are used by viewers to ascribe meaning. As students continue to paint, they will sometimes conclude their conversations by deliberately embedding conventional signs into the composition. At the end of the conversation it is not unusual to have all three modes represented in the painting. Eisner (2002) explains that representation "[s]tabilizes ideas and images, makes the editing process possible, provides for the means for sharing meaning, and creates the occasion for discovery" (p. 239).

\section{Modeling Poetry Writing}

During the second half of the workshop, I modeled for students how to use the painting as a source for a poem. Again it is important to recall Eisner's insight that representation stabilizes ideas. I borrowed one pair's art conversation (see Figure 5) and asked a student to display the painting for everyone to see. With the students, I looked closely at the painting and asked aloud what I saw going on. I deliberately modeled thinking aloud for students in order for them to hear how I was thinking (Baker \& Brown, 1984; Bereiter \& Bird, 1985; Kucan \& Beck, 1997; Olson, Duffy, \& Mack, 1984). I commented on some aspect of composition such as line, color, form, value, and movement. I also reminded students that we were investigating the question: How do you think and learn? I drew students' attention to how I placed this question in parentheses at the top of a large sheet of paper I was using to write the poem, explaining that I did not want to lose the main focus of the writing as I worked.

"Watch as I begin to write. I am going to start with what I see happening in the painting,"I told the students. I then began to write on chart paper: 
(How I Think \& Learn)

The petals, deep green shelters spring.

Colors explode.

And the sky soft blue water is lost in the riot of colors: crocus purple iris black

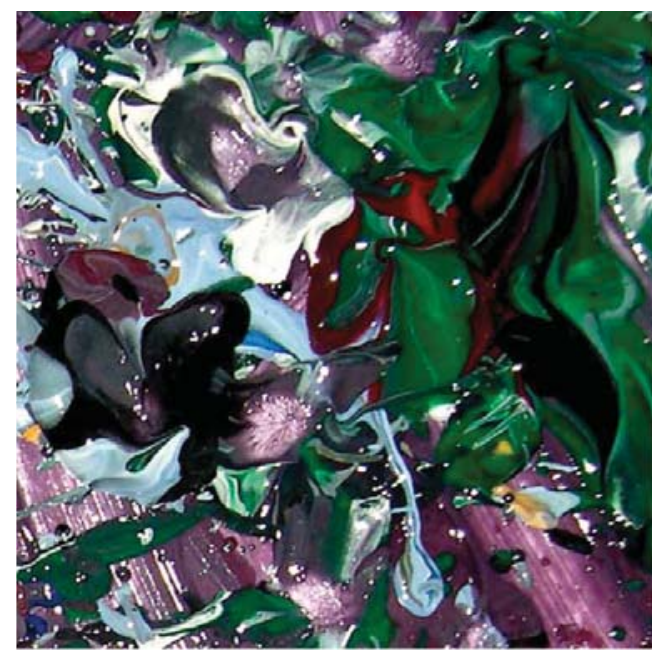

Fig. 5: Photograph of an art conversation I used to write a poem

After a minute of composing this description, I stopped and asked students how the images I had been describing might relate to how I think and learn. Students commented on how there were a lot of colors and that the painting looked like confusion. These comments were elaborated by others who added that sometimes thinking can be confusing. I continued writing about this connection, reading and rereading aloud, revising and editing my work as I composed the poem. After a few more minutes I stopped and reread the entire poem aloud, asking students to listen:

(How I Think \& Learn)

The petals, deep green

shelters spring.

Colors explode.

And the sky,

a soft blue smear of water

is lost in a riot of colors:

crocus purple,

iris black.

Thinking is like this too.

The way thoughts hide

like the sky 


\author{
backgrounded \\ yet so steady, \\ so blue beside \\ the sudden flash of color. \\ The differences between \\ reveal connections \\ I least expected.
}

When I asked students to tell what they had noticed I had done, they explained that I began by looking at the painting very carefully. Some commented that I had written words and crossed them out, as well as added new words. I included that I also reread and re-looked at the painting while writing.

"Rereading is one of the most important tools you have as a writer. Make use of it while you craft your poems,"I urged the students.

I then invited the students to study their paintings carefully by looking at the colors used, the forms and the lines employed, and the movement in order to describe what they saw going on. I adapted this inquiry-based method of viewing from Housen's (1996) and Yenawine's (2005) work on visual thinking strategies (VTS). VTS is a facilitation technique that uses art and artifacts to teach thinking. Facilitators use non-directive questions such as: What's going on in this picture? or What more can we find? to guide students' viewing.

"Try to write what you see happening,"I advised students."Remember to ask yourself how the description you are writing might connect to how you think and learn."

\title{
Students Compose Poetry
}

Students had the option of working alone at the tables where they were seated or working with a partner. After students began, I surveyed the class and then conferred with those students who seemed to be having difficulty. I invited these students to compose at stations I had set up around the room's perimeter (see Figure 6).

Large sheets of paper were posted on the walls; temporary writing stations. At each station were colorful markers. At these stations I conferred with students, 
helping them to record their initial description, often by asking them to look at the painting from different perspectives, such as looking down at the work or rotating the painting and looking again.

"What do you see here?" I prompted, pointing to a section of the painting. As students described what they were seeing aloud, I listened and then invited them to record what they had said or

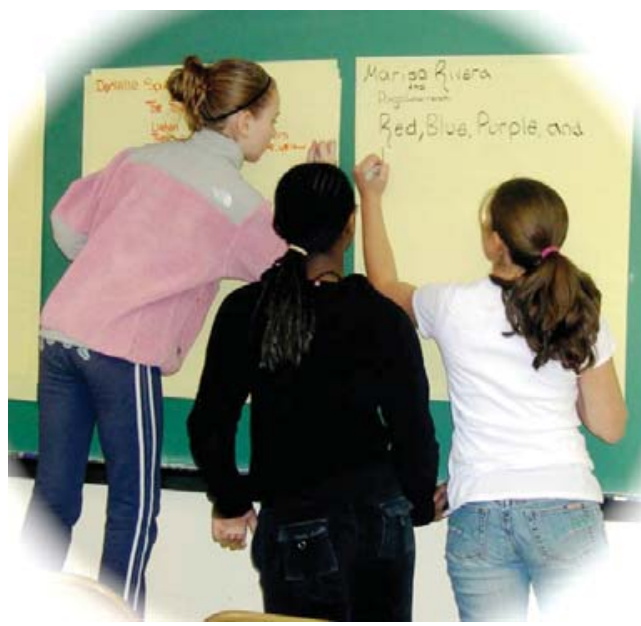

Fig. 6: Students compose poetry at a writing station wanted to say on the posted sheets of paper. At times I called attention, depending on the painted conversations, to compositional elements I saw present, such as the use of line, color, texture, shape, and movement.

As we reread, I expressed interest in the description and at times drew attention to literary elements they might have included, such as repetition, personification, alliteration, assonance, and the use of simile and metaphor. I usually concluded by asking students to consider how their poem connected with the idea of how they thought while engaged in storytelling and science.

During the workshop, the students and I revised and edited their poems. Later, I entered each student's poem into a Word ${ }^{\circledR}$ document and sent the completed documents to their classroom teachers who conferred with students to ensure the poems best matched their intentions. I also returned to the school on subsequent days to confer with students as needed. After all the revisions and editing were complete, I prepared a final copy of the book of 73 poems and art conversations. This 50-page manuscript was printed in full color and each student and teacher received a copy (Wepner et al., 2008).

\section{Transmediation}

In participating in the art conversation and poetry writing, Benjamin Franklin students used multiple sign systems (visual and written) as potential ways of learning. In doing so they engaged in transmediation - the process of making meaning 
through a range of symbol systems. The movement between and among sign systems, such as the project described here, provides students with multiple ways to come to understand concepts related to writing process and the genre of poetry. Having different means to make meaning benefits students as each method provides the potential for a new way of coming to know (Eisner, 1994, 1997, 2002; Leland \& Harste, 1994; Siegel, 1995; Suhor, 1992; Tierney, 2005).

The potential complexity inherent in different sign systems is captured well by Ludwig von Bertalanffy (1965) who wrote:

[i]f the meaning of Goethe's Faust, of Van Gogh's landscapes, or Bach's Art of the Fugue could be transmitted in discursive terms, their authors should and would not have bothered to write poems, paint, or compose, but would rather have written scientific treatises (p.41)

As Bertalanffy suggests, representation constrains and liberates thoughts. The combination of visual (word collage, slideshow, art conversation) and language (discussion, charts, written poems, voiced poems, soundtrack to slideshow) systems provided students with multiple forms of representation to learn from and to use while learning. I would suggest that this range of symbol systems helped students to compose powerful and metaphoric work.

Teaching that makes use of transmediation (Cowan \& Albers, 2006; Eisner, 1994, 1997, 2002; Leland \& Harste, 1994; Siegel, 1995, 2006; Suhor, 1992; Tierney, 2005) potentially produces more flexible thinkers, an important cognitive prowess. Eisner (1997) contends that "different forms of representation develop different cognitive skills" (p. 349). The work described here produced the potential for learners to not simply transfer their understanding as they engaged across sign systems, but rather to develop new understandings. Eisner states that "the choice of a form of representation and the selection of materials to be used both constrain and offer possibilities we use to represent what we think influences both the processes and products of thinking" (p. 349). I suggest that by thinking about the given topic through multiple representations, the end products were enhanced.

The students' teachers expressed surprise at the depth of the students' poetry and the students' willingness to engage in the art and writing. Andrzejczak, Trainin, and Poldberg (2005) studied the integration of visual arts and writing process and found that when visual art is used first there is an increase in the motivation to write and the quality of students' written work. The authors write,"[S]tudents who use 
visual art as a pre-writing stimulus are composing their ideas both in images and in words. The result of the art creation process allows students the distance to elaborate, add details, and create more coherent text" (p. 1).

By studying the images in the paintings while students wrote, this process helped them to create powerful written work. Carroll (2001) explains that when viewing visual art, meaning is comprehended perceptually, "without recourse to any subtending code" (p. 348). This direct reliance on perception facilitated an increased sophistication, resulting in the presence of figurative language in all but 12 of the students' poems. For example, 11-year-old Serena told me as we reread her poem and looked at the painted conversation, "I didn't know that's what I was thinking. I was just fooling around really and it (the painting) kinda reminded me of mud and then I thought about what you said."

"What was that?" I asked.

"You know about how this," she said pointing to the painting, "is like how I learn." Aspects of play can be seen in Serena's poem, "Sliding in the Mud" (see Figure 7). Through the finger painting, Serena and her classmates experienced the work often as a form of play. It was not unusual to hear students comment with joy about finger painting, recalling earlier experiences from when they were young children or delighting in what was a new experience. Data collected in the form of a student survey (Wepner et al., 2008) confirmed this. For example, one student wrote that what $\mathrm{s} /$ he liked best about the project was finger painting because "we got to show our emotions" (p. 34). Another indicated that his or her source of enjoyment was that students "get to make a mess with the paint" (p. 34). As Eisner (2002) comments, "In the arts ... permission is provided to explore, indeed to surrender, to the impulsions the work sends to the maker, as well as those sent from the maker to the work" (p. 4).

\section{Sliding in the Mud}

The brown squishiness of mud Beneath you as you walk And you slide a million yards.

Your wild dreams Come true.

You laugh, giggle Hard as you can.

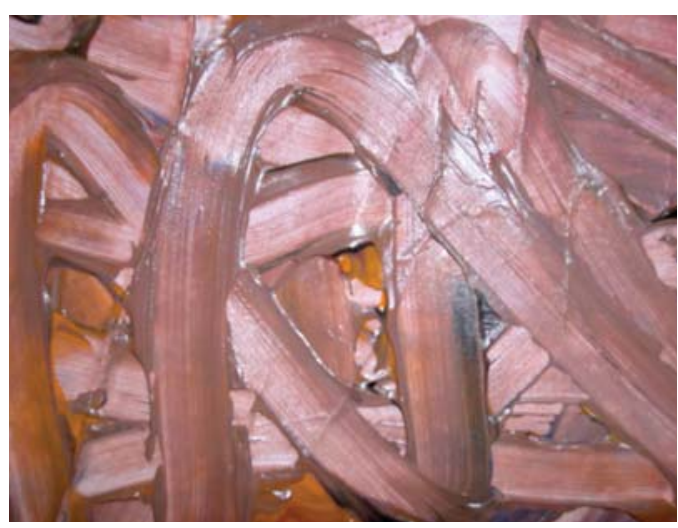

Fig. 7: Serena's poem and a detail from her art conversation 
You have fun

In that wonder

Of laughter.

A billion things

Wait for you

In this creation.

\section{The Power of Metaphor}

One sees this sense of free spiritedness in Serena's art conversation and poem. "Sliding in the Mud" captures the unexpectedness and unlimited vista of learning by comparing it to playing in mud where "[a] billion things/wait for you." Cynthia Ozick (1991) notes how "metaphor is the enemy of abstraction" (p. 282). They help make abstractions concrete, much like students did when exploring how they think and learn. Lakoff and Johnson (1980) cite metaphor as a critical tool in "trying to comprehend partially what cannot be comprehended totally: our feelings, aesthetic experiences, moral practices, and spiritual awareness" (p. 193).

Similarly, Efland (2002) suggests that visual arts stimulate the production of metaphor. Efland writes, "It is only in the arts where the processes and products of the imagination are encountered and explored in full consciousness-where they become objects of inquiry" (p. 153, emphasis in original). Working as both visual artist and interpreter, students engaged in the exploration of process and product when they painted and then studied their paintings, trying to understand better how they think and learn. By asking students to represent visually how they learned while engaged as storytellers and forensic problem-solvers, I was asking them to create mental images that were often built on nonpropositional forms of thought, such as Serena's representation of thinking as sliding in mud. Students' bodily experiences served as a primary source of the metaphors they created. This is not unusual. Again, Efland (2002), quoting Lakoff (1987) explains that,

the schemata that emerge from our bodily experience have a basic logic that enables them to form connections in at least two ways: first, things that are alike in some way can be grouped together as categories; and second, things that are seemingly unlike can be joined and made meaningful through metaphor (p. 148) 


\section{Seeing Thoughts}

The production and use of metaphors and similes in the students' poetry helps one to see the complexity inherent in students' thinking. Through art conversations and guided interpretation of the paintings, students juxtaposed images, descriptions of images, and the question,"How do you think and learn?" while composing and interpreting visual art and poetry. This movement between and among sign systems (visual, oral, and written) heightened the presence of metaphorical thinking, helping students to make concrete the abstract concept of metacognition. Without first exploring metacognition through the visual arts, I doubt the students would have been able to create such powerful metaphors that re-presented their understanding of how they think.

Again it is interesting to note that slightly less than 85 per cent of the poems students composed employed metaphorical thinking. Students compared how they thought to an abyss, a shadowy path, waves, a cave, a garden, a series of highways, a flame, outcroppings on a beach, crawling spiders, cool moonlight, a fence, something wounded, and a light beneath the darkness - to name but some.

Consider again Ariana's poem and visual conversation (see Figure 1). Ariana describes the dominant image of curved lines as "swirls of ideas (that) whirl like colors of light" where "ideas float like streams." She then sets the speaker in a boat with an oar and the desire to get to "the shore." One can easily imagine the boat floating along the current of a stream like a "butterfly in the breeze." In such an environment, ideas flow. Ariana states, "learning is the key." One might surmise here that learning is the key because knowledge is made not simply by having an experience, but rather by understanding the experience-getting to the shore.

Similar to Ariana's and Serena's use of metaphor, Reynaldo too leans on metaphorical thinking to convey meaning in his poem, "Rainbow" (see Figure 8). The speaker in Reynaldo's poem writes how the moon is his mind and knowledge is beams of light that pour and blend color. Reynaldo begins by describing a surreal landscape in which both moonlight and a rainbow are present late at night in a meadow. He then bridges the poem with a two-line stanza stating the moon is the speaker's mind. The closing stanza, reminiscent of the opening one, now juxtaposes the surreal external landscape with an internal one where knowledge like the moon lights the speaker internally. 


\section{Rainbow}

The moon

In the sky

Shines

Beams

Of light on

A rainbow

Late night

In the meadow.

The moon

Is my mind.

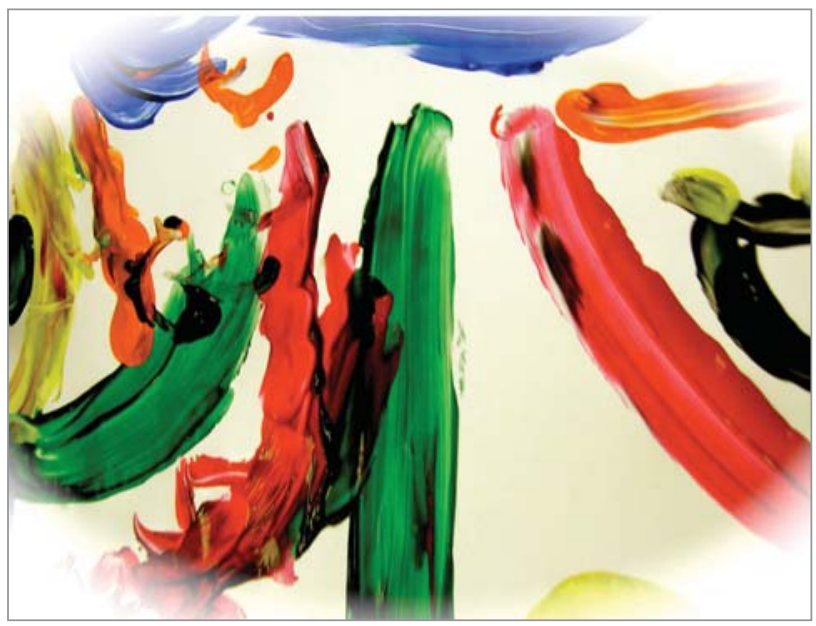

Fig. 8: Reynaldo's poem and a detail from his art conversation

The beams

Are moments

Of knowledge

That blend

And pour-

Spilling color

And light

Into me

Like a rainbow.

\section{Saying of What You See in the Dark: Valuing the Imagination in a Time of Testing}

The insights composed by Ariana, Serena, and Reynaldo about how they think and learn remind me of the advice given by the guitarist in Wallace Stevens's (1990) "The Man With the Blue Guitar" who says: "Throw away the lights, the definitions/And say of what you see in the dark" (p. 183). In many ways, these students do exactly that: they look at the visual conversations they have composed and then say what they have seen through poetry. Art conversations and poetry writing workshops nudge students to imagine and name aspects of living that they may have previously noticed, yet remained unvoiced-ruminations that may well have been present in some fashion in their lives-in their visceral experiences.

At a time when the annual state tests often drive curricular decisions, how might one then answer critics who query: "How do art conversations and poetry writing 
help students pass the state exam?" Apart from the more direct correlations between arts integration and increased student performance on high stakes tests (Andrzejczak, Trainin, \& Poldberg, 2005; Reilly, 2008; Catterall, Chapleau, \& Iwanga, 1999; Deasy, 2002; Eisner, 2002; Newmann, Bryk, \& Nagaoka, 2001), the work described in this article also suggests that the integration of visual arts and writing enhances students' habits of mind (Costa \& Kallick, 2000).

Costa and Kallick (2000) identified 16 types of intelligent behavior (see Figure 9) that they captured as habits of mind. Most of these habits were present in the work students did to compose visual and written products, though some were more prominent than others. For example, thinking and communicating with clarity and precision; creating, imagining, and innovating; thinking flexibly; thinking about thinking; applying past knowledge to new situations; and remaining open to continuous learning were central to most aspects of the art and poetry project. Whereas art conversations and poetry workshops might not directly prepare students for a particular state assessment at the surface-the thinking dispositions and behaviors developed through such teaching and learning would most certainly enhance students' cognitive performance and aesthetic sensibilities and in doing so prepare students for the deeper learning represented on some high stakes assessments.

\begin{tabular}{|ll|}
\hline 1. & Persisting \\
2. & Thinking and communicating with clarity and precision \\
3. & Managing impulsivity \\
5. & Gathering data through all senses \\
6. & Creating, imagining, innovating \\
7. & Thinking flexibly \\
8. & Responding with wonderment and awe \\
9. & Thinking about thinking (metacognition) \\
10. & Taking responsible risks \\
11. & Striving for accuracy \\
12. & Finding humor \\
13. & Questioning and posing problems \\
14. & Thinking interdependently \\
15. & Applying past knowledge to new situations \\
16. & Remaining open to continuous learning
\end{tabular}

Fig. 9: Habits of mind 
Seeing beneath the surface-peering into the darkness-is brave and necessary work that needs to be done not only by students, but also by educators. At a time when high stakes testing has gained a disproportional emphasis (Berliner \& Biddle, 1996; Nichols \& Berliner, 2007; Noddings, 2007), we need to guard against the displacement of thinking in lieu of practicing for tests. Noddings (2007) contends, "the overemphasis on testing and the use of test scores as the main measure of accountability may actually undermine the development and exercise of intellectual habits of mind" (p. 64).

Preparing for tests is not equivalent to educating one to learn. In such a schema, the imagination and the child may well be forgotten. Educating the imagination is about transformation, unsettling the known, disturbing held truths. One surely thinks here of Maxine Greene and her many inquiries into teaching and learning. In Releasing the Imagination (1995), Greene writes,

Aesthetic experiences require conscious participation in a work, a going out of energy, an ability to notice what is there to be noticed.....Knowing 'about' is entirely different from constituting a fictive world imaginatively and entering it perceptually, affectively, and cognitively (p. 125).

In designing this art and writing experience, I wanted to occasion the possibility for students to begin to name how they learn, not from the stance of simply knowing about learning, but more so as Greene suggests to understand thinking and learning within the constituted fictive worlds of their imagination. Such imaginative work develops students' capacity to recognize and name patterns, an underlying function of thinking. Lowry (2001) explains that:

to construct knowledge, the brain takes in data through the sensory perceptions, that enter through the body's five senses. Anything that a person does, perceives, thinks, or feels while acting in the world is processed through the complex system of storage and pathways (p. 179).

Similarly, the students commented via an exit survey (Wepner et al., 2008, pp. 32-33) that they learned how to communicate, how to imagine, how to write poems, how to use pictures as sources for poetry, and how to tell stories, while engaged in the art and writing work. Additionally, one student captured Lowry's notion of knowledge construction, by writing, "you can get literate from a picture you painted" (Wepner et al., 2008, p. 32). 
In reading these student comments I thought about Dewey (1954) who in The Public and Its Problems noted, "the function of art has always been to break through the crest of conventionalized and routine consciousness" (p. 183). Through transmediated learning, Ariana's row toward a distant shore, Serena's slide through mud, and Reynaldo's internally lit landscape unseat routine consciousness, recast the ordinary, and perhaps, like Stevens's guitarist, inspire each of us to peer into the dark.

\section{References}

Andrzejczak, N., Trainin, G., \& Poldberg, M. (2005). From image to text: Using images in the writing process. International Journal of Education and the Arts, 6(12), 1-17.

Baker, L., \& Brown, A. (1984). Metacognitive skills and reading. In P.D. Pearson (Ed.), Handbook of reading research. White Plains, NY: Longman.

Bereiter, C., \& Bird, M. (1985). Use of thinking aloud in identification and teaching of reading comprehension strategies. Cognition and Instruction, 2(2), 131-156.

Berliner, D., \& Biddle, B. (1996). The manufactured crisis: Myths, fraud, and the attack on America's public schools. New York: Perseus Books.

Carroll, N. (2001). Beyond aesthetics: Philosophical essays. Cambridge, UK: Cambridge University Press.

Catterall, J. A., Chapleau R., \& Iwanga, J. (1999). Involvement in the arts and human development: General involvement and intensive involvement in music and theatre arts. In E. B. Fiske (Ed.), Champions of change: The impact of the arts on learning. Washington, D.C.: President's Committee on the Arts and Humanities.

Costa, A., \& Kallick, B. (2000). Habits of mind: A developmental series. Alexandria, VA: Association for Supervision and Curriculum Development.

Cowan, K., \& Albers, P. (2006). Semiotic representations: Building complex literacy practices through the arts. The Reading Teacher, 60(2), 124-137.
Deasy, R. (Ed.). (2002). Critical links: Learning in the arts and student academic social development. Washington, D.C.: Arts Education Partnership.

Dewey, J. (1954). The public and its problems. Athens, $\mathrm{OH}$ : Swallow Press.

Efland, A. D. (2002). Art and cognition: Integrating the visual arts in the curriculum. New York \& VA: Teachers College Press \& National Art Education Association.

Eisner, E. (1994). Cognition and curriculum reconsidered. New York: Teachers College Press.

Eisner, E. (1997). Cognition and representation: A way to pursue the American dream? Phi Delta Kappan, 78(5), 348-354.

Eisner, E. (2002). The arts and the creation of mind. New Haven, CT:Yale University Press.

Greene, M. (1995). Releasing the imagination: Essays in education, the arts, and social change. San Francisco: Jossey-Bass Inc.

Housen, A. (1996). Studies on aesthetic development. Minneapolis, MN: American Association of Museums Sourcebook.

Kucan, L., \& Beck, I. (1997). Thinking aloud and reading comprehension research: Inquiry, instruction, and social interaction. Review of Educational Research, 67, 271-299.

Lakoff, G., \& Johnson, M. (1980). Metaphors we live by. Chicago: University of Chicago Press.

Leland, C., \& Harste, J. (1994). Multiple ways of knowing: Curriculum in a new key. Language Arts, 71(5), 337-345. 
Lowry, L.F. (2001). The biological basis for thinking. In A.L. Costa's (Ed). Developing minds: A resource book for teaching thinking ( $\mathrm{pp}$. 175-180). Alexandria, VA: Association for Supervision and Curriculum Development.

Newmann, F. M., Bryk, A. S., \& Nagaoka, J. K. (2001). Authentic intellectual work and standardized tests: Conflict or coexistence? Improving Chicago's schools. Chicago: The J. Paul Getty Trust.

Nichols, S., \& Berliner, D. (2007). Collateral damage: How high-stakes testing corrupts America's schools. Cambridge, MA: Harvard Education Press.

Noddings, N. (2007). When school reform goes wrong. New York: Teachers College Press.

Olson, G., Duffy, S., \& Mack, R. (1984). Thinkingout-loud as a method for studying realtime comprehension processes. In D. Kieras \& M. Just (Eds.), New methods in reading comprehension research (pp. 253-286). Hillsdale, NJ: Lawrence Erlbaum.

Ozick, C. (1991). Metaphor and memory: Essays. New York: Knopf.

Reilly, M.A. (2008). Finding the right words: Art conversations and poetry. Language Arts, 86(2), 19-27. Urbana, IL: National Council of Teachers of English.

Reilly, M.A., \& Cohen, R. (2008). Sowing seeds of social justice through performative pedagogy: Middle school students explore genocide. In T. Huber-Warring (Series Ed.), Growing a soul for social change: Building the knowledge base for social justice (pp. 383-398). Teaching < > Learning indigenous, intercultural worldviews: International perspectives on social justice and human rights (premiere vol. in this series). Charlotte, NC: Information Age Publishing.
Reilly, M.A., \& Gangi, J.M. (In press). Deepening literacy learning: Art and literature engagements in K-8 classrooms. Charlotte, NC: Information Age Publishing.

Siegel, M. (1995). More than words: The generative power of transmediation for learning. Canadian Journal of Education, 20, 455-475.

Siegel, M. (2006). Adding the signs: Multimodal transformations in the field of literacy. Language Arts, 84, 65-77.

Suhor, C. (1992). Semiotics and English language arts. Language Arts, 69, 228-230.

Stevens, W. (1990). "The Man with the Blue Guitar" in The Collected poems of Wallace Stevens (165-184). New York: Vintage.

Tierney, R.J. (2005). Learning with multiple symbol systems: possibilities, realities, paradigm shifts and developmental considerations. In J. Flood, S. B. Heath, \& D. Lapp (Eds.). Handbook of research on teaching literacy through the communicative and visual arts (286-299). Mahwah, NJ: Lawrence Erlbaum.

v. Bertalanffy, L. (1965). On the definition of symbol. In J. R. Royce (Ed.). Psychology and the symbol (pp. 26-72). New York: Random House.

Wepner, S.B., Bettica, A., Gangi, J.M., Reilly, M.A., \& Klemm, T.T. (2008). Developing a schoolcollege professional learning community to promote student engagement. Ecelsior: Leadership in Teaching and Learning, 3(1), 27-45.

Yenawine, P. (2005). Thoughts on visual literacy. In J. Flood, S. B. Heath, \& D. Lapp (Eds.). Handbook of research on teaching literacy through the communicative and visual arts (845-846). Mahwah, NJ: Lawrence Erlbaum. 


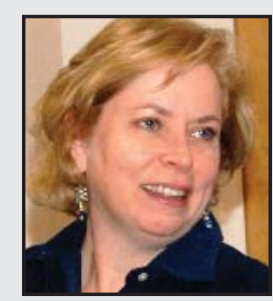

Mary Ann Reilly is an educator and fine arts photographer who has worked as a K-12 teacher, director and assistant superintendent for urban public schools in New Jersey. Most recently she worked as an associate professor at Manhattanville College in Purchase, New York, before returning to the Morris School District in New Jersey where she works as the Director of Professional Learning. She is the coauthor, along with Jane M. Gangi, of the forthcoming book, Deepening Literacy Learning: Art and Literature Engagements in K-8 Classrooms (IAP Publisher).

\section{LINK TO:}

http://www.maryannreilly.mosaicglobe.com 